\title{
The contribution of peroxynitrite generation in HIV replication in human primary macrophages
}

\author{
Stefano Aquaro ${ }^{\dagger 1,2}$, Carolina Muscoli ${ }^{\dagger 3,4}$, Alessandro Ranazzi ${ }^{1}$, \\ Michela Pollicita ${ }^{1}$, Teresa Granato ${ }^{5}$, Laura Masuelli ${ }^{1}$, Andrea Modesti ${ }^{1}$, Carlo- \\ Federico Perno ${ }^{1}$ and Vincenzo Mollace ${ }^{* 3,4,6}$
}

Address: ${ }^{1}$ Department of Experimental Medicine and Biochemical Sciences, University of Tor Vergata, Rome, Italy, ${ }^{2}$ Department of PharmacoBiology, University of Calabria, Rende(CS), Italy, ${ }^{3}$ Faculty of Pharmacy, University of Catanzaro "Magna Graecia", Roccelletta di Borgia, Catanzaro, Italy, ${ }^{4}$ San Raffaele Pisana IRCCS, Rome, Italy, 5 IBPM-CNR, Rome, Italy and ${ }^{6}$ Istitute Mondino-Tor Vergata, Rome, Italy

Email: Stefano Aquaro - aquaro@uniroma2.it; Carolina Muscoli - muscoli@fastwebnet.it; Alessandro Ranazzi - ranazzi@uniroma2.it; Michela Pollicita - pollicita@uniroma2.it; Teresa Granato - granato@libero.it; Laura Masuelli - masuelli@uniroma1.it;

Andrea Modesti - modesti@uniroma2.it; Carlo-Federico Perno - perno@uniroma2.it; Vincenzo Mollace* - mollace@unicz.it

* Corresponding author †Equal contributors

Published: 21 October 2007

Retrovirology 2007, 4:76 doi:10.1 186/1742-4690-4-76

This article is available from: http://www.retrovirology.com/content/4/I/76

(C) 2007 Aquaro et al; licensee BioMed Central Ltd.

This is an Open Access article distributed under the terms of the Creative Commons Attribution License (http://creativecommons.org/licenses/by/2.0), which permits unrestricted use, distribution, and reproduction in any medium, provided the original work is properly cited.

\begin{abstract}
Background: Monocytes/Macrophages (M/M) play a pivotal role as a source of virus during the whole course of HIV-I infection. Enhanced oxidative stress is involved in the pathogenesis of HIVI infection. HIV-I regulatory proteins induce a reduction of the expression and the activity of MnSOD, the mitochondrial isoform leading to a sustained generation of superoxide anions and peroxynitrite that represent important mediators of HIV-I replication in M/M. MnTBAP (Mn(III)tetrakis(4-benzoic acid)porphrin chloride), a synthetic peroxynitrite decomposition catalyst, reduced oxidative stress subsequent to peroxynitrite generation.
\end{abstract}

Results: Virus production was assessed by p24 ELISA, western blot, and electron microscopy during treatment with MnTBAP. MnTBAP treatment showed a reduction of HIV-I replication in both acutely and chronically infected M/M: $99 \%$ and $90 \%$ inhibition of p24 released in supernatants compared to controls, respectively. Maturation of p55 and p24 was strongly inhibited by MnTBAP in both acutely and chronically infected $\mathrm{M} / \mathrm{M} . \mathrm{EC}_{50}$ and $\mathrm{EC}_{90}$ are $3.7( \pm 0.05) \mu \mathrm{M}$ and $19.5( \pm 0.5)$ $\mu \mathrm{M}$, in acutely infected $\mathrm{M} / \mathrm{M} ; 6.3( \pm 0.003) \mu \mathrm{M}$ and $30( \pm 0.6) \mu \mathrm{M}$, in chronically infected $\mathrm{M} / \mathrm{M}$. In acutely infected peripheral blood limphocytes (PBL), $\mathrm{EC}_{50}$ and $E C_{90}$ are $7.4( \pm 0.06) \mu \mathrm{M}$ and of 21.3 $( \pm 0.6) \mu M$, respectively. Treatment of acutely-infected $M / M$ with MnTBAP inhibited the elevated levels of malonildialdehyde (MDA) together with the nitrotyrosine staining observed during HIV-I replication. MnTBAP strongly reduced HIV-I particles in infected $M / M$, as shown by electron microscopy. Moreover, in presence of MnTBAP, HIV-I infectivity was reduced of about I log compared to control.

Conclusion: Results support the role of superoxide anions in HIV-I replication in M/M and suggest that MnTBAP may counteract HIV-I replication in combination with other antiretroviral treatments. 


\section{Background}

It is well know that monocytes/macrophages $(M / M)$ are important targets of human immunodeficiency virus type 1 (HIV-1) in infected patients. Such cells are widely recognized to play a pivotal role as a source of virus during the whole course of HIV-1 infection, even in patients receiving antiretroviral therapy [1]. HIV-1 infection does not lead to $\mathrm{M} / \mathrm{M}$ depletion as occurs for HIV-1 infected $\mathrm{CD}_{4}{ }^{+}$ T-lymphocytes; instead, once infected by HIV-1, M/M produce large amounts of infectious viral particles for a long period of time [2]. Productively infected $\mathrm{M} / \mathrm{M}$ can fuse with $\mathrm{CD} 4^{+} \mathrm{T}$-lymphocytes and transfer the virus to these cells within the context of antigen presentation [3]; in addition, infected $\mathrm{M} / \mathrm{M}$ are able to trigger apoptosis of $\mathrm{T}$ lymphocytes (either CD4+ ${ }^{+}$or CD $8^{+}$) [4-6] as well as astrocytes, [7-9]. Few HIV-infected $M / M$ are sufficient to induce the recruitment and activation of HIV-infected resting CD4+ lymphocytes [10] and infect resting CD4+ T-lymphocytes [11]. Recently, it has been demonstrated that as few as $500 \mathrm{HIV}$-exposed $\mathrm{M} / \mathrm{M}$ cause complete depletion of several millions of autologous CD4+ T-lymphocytes, sustained HIV-viremia and spreading of HIV-1-DNA in mouse lymphoid organs [12]. Therefore, $\mathrm{M} / \mathrm{M}$ sustain persistent and continuously productive HIV infection [13]. Moreover, evidence exists suggesting that enhanced oxidative stress may be involved in the pathogenesis of HIV infection and HIV-1-infected patients are under chronic oxidative stress [14-16]. The activation of CD4+ T-lymphocytes and $\mathrm{M} / \mathrm{M}$, which occurs during HIV infection, is most likely due to increased production of free radicals such as superoxide anion, peroxynitrite (the by-product of super oxide and nitric oxide, NO) and hydroxyl radical which is generated by peroxynitrite decomposition $[8,17]$. In addition, elevated serum levels of hydroperoxides and malondialdehyde (MDA), which are recognized as markers of lipid peroxidation subsequent to free radical overproduction, have also been found in asymptomatic HIV1 -infected patients early in the course of the disease [18]. Under normal circumstances, in healthy individuals, the free radicals burden is highly regulated by the endogenous antioxidant systems (i.e. superoxide dismutase enzymes, SOD) and glutathione peroxidase. Previous studies suggest that oxidative stress plays a crucial role during HIV-1 pathogenesis, including viral replication, inflammatory response, decreased immune cell proliferation, loss of immune function, chronic weight loss and increased sensitivity to drug toxicity. In particular, the disruption of oxidative status contributes to the cell damage observed during HIV-1 infection, yet it is worth stressing that such alteration is particularly relevant in $\mathrm{M} / \mathrm{M}[18,19]$. The alteration of the homeostasis induced by HIV-1 infection in $\mathrm{M} / \mathrm{M}$, with consequent production of toxic factors, is claimed to be the main cause of neuronal damage during AIDS [17]. In particular, the release of some coating component of HIV-1, such as gp120 glycoprotein by HIV-1- infected $\mathrm{M} / \mathrm{M}$ produces both direct and indirect effects in the central nervous system (CNS) and in the systemic compartment $[20,21]$. The neuronal injury can result from a direct mechanism by interaction with viral proteins, such as gp120, Tat (Transcriptional transactivator) and $\operatorname{Vpr}$ (viral protein $\mathrm{R}$ ) produced by infected cells, or by an indirect effect resulting from the inflammatory process involving activated, though not necessarily HIV-1infected, monocytes, macrophages and astrocytes [22]. Furthermore, HIV-1 infection induces a significant perturbation of oxidative status of $\mathrm{M} / \mathrm{M}$ associated with an increased production of MDA and a decreased synthesis of endogenous glutathione [18]. In addition, the HIV regulatory proteins induce a reduction of expression and activity of MnSOD, the mitochondrial isoform of the enzyme [23], leading to a sustained generation of superoxide and peroxynitrite and in turn imbalance of the cellular homeostasis [24,25].

The associations of HIV infection with the formation of free radical species led us to hypothesize that superoxide and peroxynitrite may represent important mediators of M/M-HIV replication. To test this, we employed MnTBAP (Mn(III)tetrakis(4-benzoic acid)porphrin chloride), a synthetic peroxynitrite decomposition catalyst proven to reduce oxidative stress subsequent to peroxynitrite generation $[9,26]$.

\section{Results}

\section{Acutely-infected macrophages}

A significant dose dependent antiviral activity of MnTBAP was achieved in acutely-infected $M / M$ (i.e. treated with drugs prior to virus challenge). In particular, the $1.2 \mu \mathrm{M}$ dose of MnTBAP led to a reduction of p24 gag Ag production down to about $15 \%$ (Fig. 1). Indeed, concentration of $30 \mu \mathrm{M}$ completely inhibited HIV-1 replication up to day 14 , end of experiment, affording undetectable levels of p24 gag Ag production (Fig. 1), no signs of toxicity were observed at $30 \mu \mathrm{M}$ (data not shown). Interestingly, virus inhibition remained constant for all concentrations tested up to day 14 (data not shown). Therefore, neither major breakthrough nor cumulative inhibition of virus replication occurred in acutely-infected $\mathrm{M} / \mathrm{M}$ at least up to 14 days after infection. $\mathrm{EC}_{50}$ and $\mathrm{EC}_{90}$ were then calculated and found to be $3.7( \pm 0.05) \mu \mathrm{M}$ and $19.5( \pm 0.5) \mu \mathrm{M}$, respectively (Table 1$)$.

\section{Chronically-infected macrophages}

To study the activity of MnTBAP in chronically-infected $\mathrm{M} / \mathrm{M}$, antiviral treatment was started 10 days after infection, when both HIV-1 p24 gag Ag (Fig. 2) and genomic HIV-RNA (data not shown) released in the supernatants show a stable virus production. A decrease in the release of mature proteins, compared to control, was already detectable by day 5 after drug treatment with the highest 


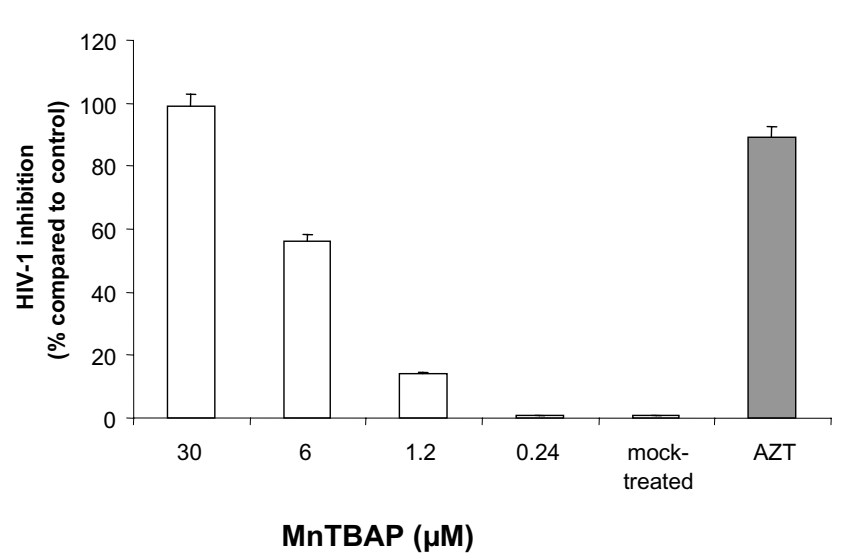

Figure I

Antiviral activity of MnTBAP in acutely HIV-I infected macrophages. Monocytes were cultured for 5 days to generate monocyte-derived macrophages which where infected with 300 TCID50/ml HIV-I BaL and treated acutely (i.e. treated with drugs prior to virus challenge). Supernatants were collected day I 4 after infection and tested for virus production by analysis of HIV-I P24 gag Ag production with a commercially available kit ELISA.

concentrations of MnTBAP (30 $\mu \mathrm{M}$ and $6 \mu \mathrm{M}$ ) (Fig. 2), and become more pronounced at day $10(30 \mu \mathrm{M})$. This event was similar to the inhibition observed when amprenavir $(4 \mu \mathrm{M})$, a protease inhibitor employed as control of chronic inhibition, was employed. Starting from day 5 of drug treatment, and until the end of the experiment, a quasi-stable and substantial inhibition of the release of HIV-1 p24 gag Ag was detected with concentrations of MnTBAP of 6 and $30 \mu \mathrm{M}$ (about $50 \%$ and $90 \%$ at day 5, respectively) up to day 10 after treatment. No complete inhibition of virus replication could be achieved at the highest non-toxic concentrations tested (Fig. 2). Based on these data, $\mathrm{EC}_{50}$ and $\mathrm{EC}_{90}$ of MnTBAP were $6.3( \pm 0.003)$ $\mu \mathrm{M}$ and $30( \pm 0.6) \mu \mathrm{M}$, respectively (Table 1$)$. Treatment with $10 \mu \mathrm{M}$ of AZT (about 200-fold greater than its $\mathrm{EC}_{90}$ in HIV-1-acutely infected $\mathrm{M} / \mathrm{M}$ ) was not able to reduce the production of HIV-1-p24 gag Ag in chronically infected $\mathrm{M} / \mathrm{M}$ (data not shown). This further confirms the absence of new rounds of replication in these cells after day 10 of infection $[2,27]$.

\section{Acutely-infected PBL}

We wished to compare these results with those obtained using protease inhibitors in PBL. MnTBAP has shown a stable antiviral activity in acutely infected PBL until the end of the experiment (day 10 after infection), with an $\mathrm{EC}_{50}$ of $7.4( \pm 0.06) \mu \mathrm{M}$ and an $\mathrm{EC}_{90}$ of $21.3( \pm 0.6) \mu \mathrm{M}$ (Table 1). These $\mathrm{EC}_{50}$ and $\mathrm{EC}_{90}$ are and in the range (or lower in the case of $\mathrm{EC}_{90}$ ) of those determined in acutely infected $\mathrm{M} / \mathrm{M}$ (Table 1).

\section{Drug toxicity}

Treatment of M/M and PBL with concentrations of MnTBAP showed no decrease in cell number, thus suggesting the absolute absence of major toxicity at used concentrations (Table 1). Thus, the antiviral activity observed in these experiments can be attributed only to the MnTBAP inhibitory effect.

\section{HIV-I p24 and p55 gag proteins analysis}

The western blots of lysates of acutely and chronically infected $M / M$ treated with MnTBAP are shown in Fig. 3 . When the M/M lysates were examined, the inhibition of HIV-1-p24 antigen release into the supernatants correlated with the disappearance of the p24 band in the immunoblots in both acutely and chronically infected $\mathrm{M}$ / M. Interestingly, HIV-1 p55 antigen was also inhibited by MnTBAP treatment (Fig. 3 ) showing that MnTBAP is able to counteract both the p24 as the precursor p55 formation, revealing the ability of MnTBAP to block the maturation of p24 viral protein.

\section{Selective inactivation of peroxynitrite in HIV-I infected macrophges}

Furthermore, HIV-1 replication was associated with an increase of MDA level and nitrotyrosine staining indicating the HIV-related peroxynitrite formation (Fig. 4, 5A) as evaluated 14 days after HIV-infection. Treatment of acutely-infected $\mathrm{M} / \mathrm{M}$ with MnTBAP $(0,24-30 \mu \mathrm{M})$ inhibited the MDA formation in a dose response manner (Fig.

Table I: Comparative anti-HIV-I efficacy of MnTBAP in macrophages and lymphocytes

\begin{tabular}{cccc}
\hline Cells & $\mathrm{EC}_{50}(\mathrm{mM})$ & $\mathrm{EC}_{90}(\mathrm{mM})$ & $\mathrm{TC}_{50}(\mathrm{mM})$ \\
\hline $\begin{array}{c}\text { Macrophages } \\
\text { Acutely infected } \\
\text { Cronically infected }\end{array}$ & $3.7( \pm 0.05)$ & $19.5( \pm 0.5)$ & 60 \\
$\begin{array}{c}\text { Limphocytes } \\
\text { Acutely infected }\end{array}$ & $6.3( \pm 0.003)$ & $30( \pm 0.6)$ & 60 \\
& $7.4( \pm 0.06)$ & $21.3( \pm 0.6)$ & 50 \\
\hline
\end{tabular}

The geometric mean of 24 gag Ag production of replicates in each experiment was used to determine the effective drug concentration where $50 \%$ and $90 \%$ of viral replication is inhibited (EC50 and EC 90 , respectively), by linear regression of the log of the percent HIV-I-p24 production (compared to untreated controls) versus the log of the drug concentration. TC50: toxic concentration 50\%; drug toxicity has been assessed in the absence of viral infection. 


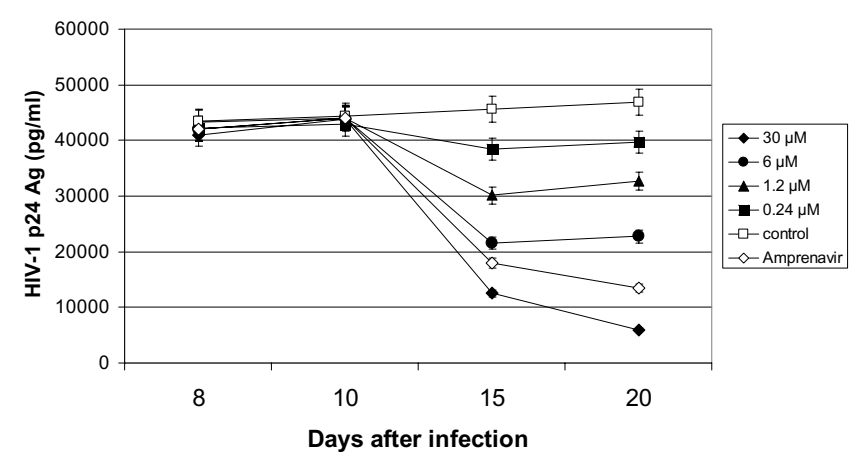

Figure 2

Antiviral activity of MnTBAP in chronically HIV-I infected macrophages. Monocytes were cultured for 5 days to generate monocyte-derived macrophages which where infected with 300 TCID50/ml HIV-I BaL and treated chronically (i.e. treated with drugs 10 days after infection) with MnTBAP at indicated doses, and Amprenavir (4 uM). Supernatants were collected at day 8, 10, I5, 20 after infection and tested for virus production by analysis of HIV-I p24 gag $\mathrm{Ag}$ production with a commercially available kit ELISA.

4) and nitrotyrosine staining observed during HIV-1 replication ( $30 \mu \mathrm{M}$; Fig. 5D) by removing the superoxide and peroxynitrite formation. As a control and consistent with previously published data, $0.05 \mu \mathrm{M}$ AZT induced about $90 \%$ inhibition of virus replication in these acutely infected M/M (Fig. 1), but did not affected the nitrotyrosine staining nor MDA level (Fig. 4, 5C).

\section{Effects of MnTBAP upon virus infectivity}

We investigated the production of infectious virus particles by both acutely and chronically infected M/M. Super-

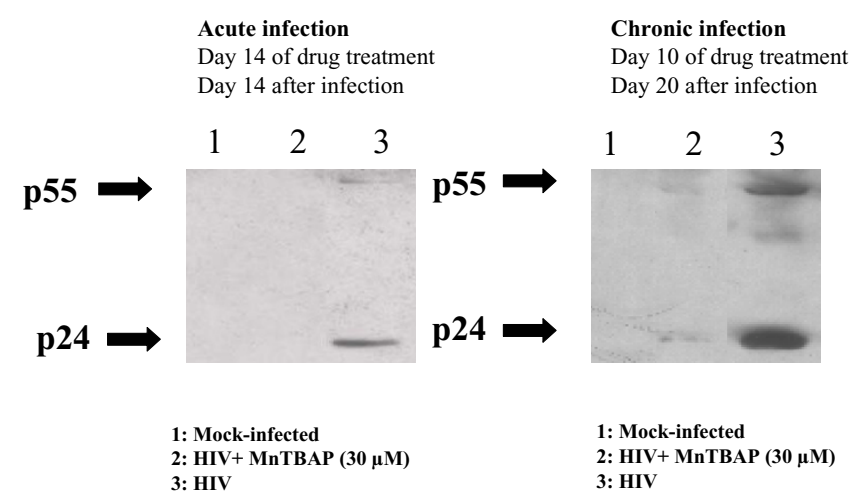

Figure 3

MnTBAP reduces p24 and p55 expression in HIVinfected macrophages. Western blots of lysates of acutely and chronically infected M/M. Line I: Mock-infected macrophages. Line 2: macrophages HIV-I BaL infected and treated with MnTBAP (30 $\mu \mathrm{M})$. Line 3: macrophages HIV-I BaL infected.

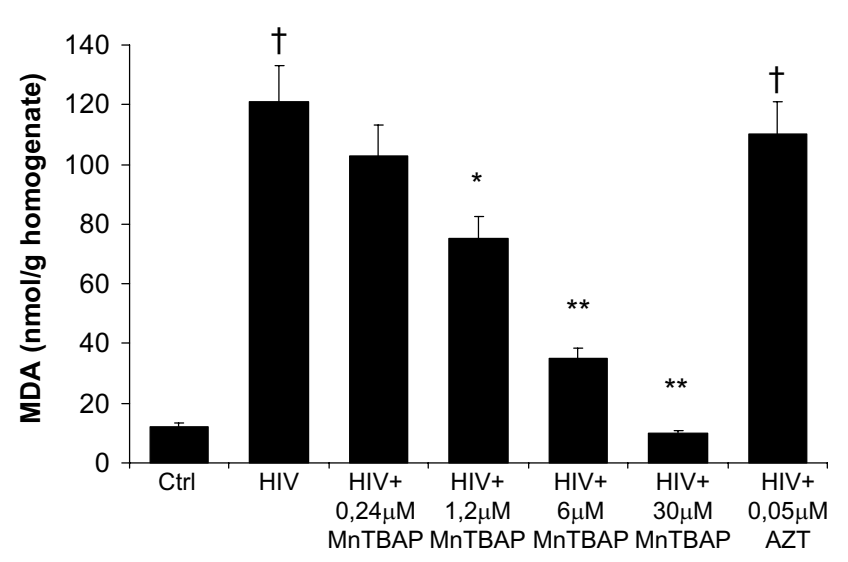

\section{Figure 4}

MnTBAP inhibits MDA in HIV-infected macrophages in a dose dependent fashion. MDA increased within HIVI-infected macrophages. Treatment with MnTBAP $(0,24-30$ $\mu \mathrm{M})$ antagonized MDA overproduction dose-dependently while AZT $(0.05 \mu \mathrm{M})$ was not able to inhibit macrophages HIV-related MDA formation. $\dagger P<0.001$ when compared to control; $* \mathrm{P}<0.05$ and $* * \mathrm{P}<0.00$ I when compared to HIVinfected cells.

natants of HIV-1 acutely and chronically infected $\mathrm{M} / \mathrm{M}$ previously treated with MnTBAP $6 \mu \mathrm{M}$ and $30 \mu \mathrm{M}$, respectively, were titered in cultures of $\mathrm{M} / \mathrm{M}$ and compared with the infectivity of not treated HIV-1 infected M/M supernatants taken at the same time-point. The infectivity of supernatants of not treated HIV-1 acutely infected M/M had a titer of $6.57 \times 10^{3} \mathrm{TCID}_{50} / \mathrm{ml}$ (Fig. 6A), while supernatants from MnTBAP ( $6 \mu \mathrm{M})$ treated HIV-infected M/M showed a not detectable infectivity (Fig. 6A). Similarly, the infectivity of supernatants of not treated HIV-1 chronically infected $\mathrm{M} / \mathrm{M}$ had a titer of $5.62 \times 10^{3} \mathrm{TCID}_{50} / \mathrm{ml}$ (Fig. 6B), while supernatants from MnTBAP $(30 \mu \mathrm{M})$ treated HIV-infected $\mathrm{M} / \mathrm{M}$ had a titer of $4.21 \times 10^{2} \mathrm{TCID}_{50} /$ $\mathrm{ml}$ (Fig. 6B), that means a reduction of more than $92 \%$ of infectivity.

\section{Ultrastructural analysis of acutelly-infected M/M treated with MnTBAP}

In order to better understand the mechanism through which the removal of peroxynitrite was acting on HIV-1 acutely infected $\mathrm{M} / \mathrm{M}$, electron microscopy was performed at day 14 after treatment. It is know that the mature HIV1 particles are accumulated in intracytoplasmic vacuoles in $\mathrm{M} / \mathrm{M}$ before the budding. As shown in Figure 7, MnTBAP at concentration of $6 \mu \mathrm{M}$ dramatically reduced the presence of HIV-1 particles inside cytoplasmic vacuoles and in the extracellular compartment (Fig. 7). Moreover, the number of these cytoplasmic vacuoles was dimished by MnTBAP treatment in HIV-1-infected M/M, compared to untreated HIV-1-infected $\mathrm{M} / \mathrm{M}$. These observations 

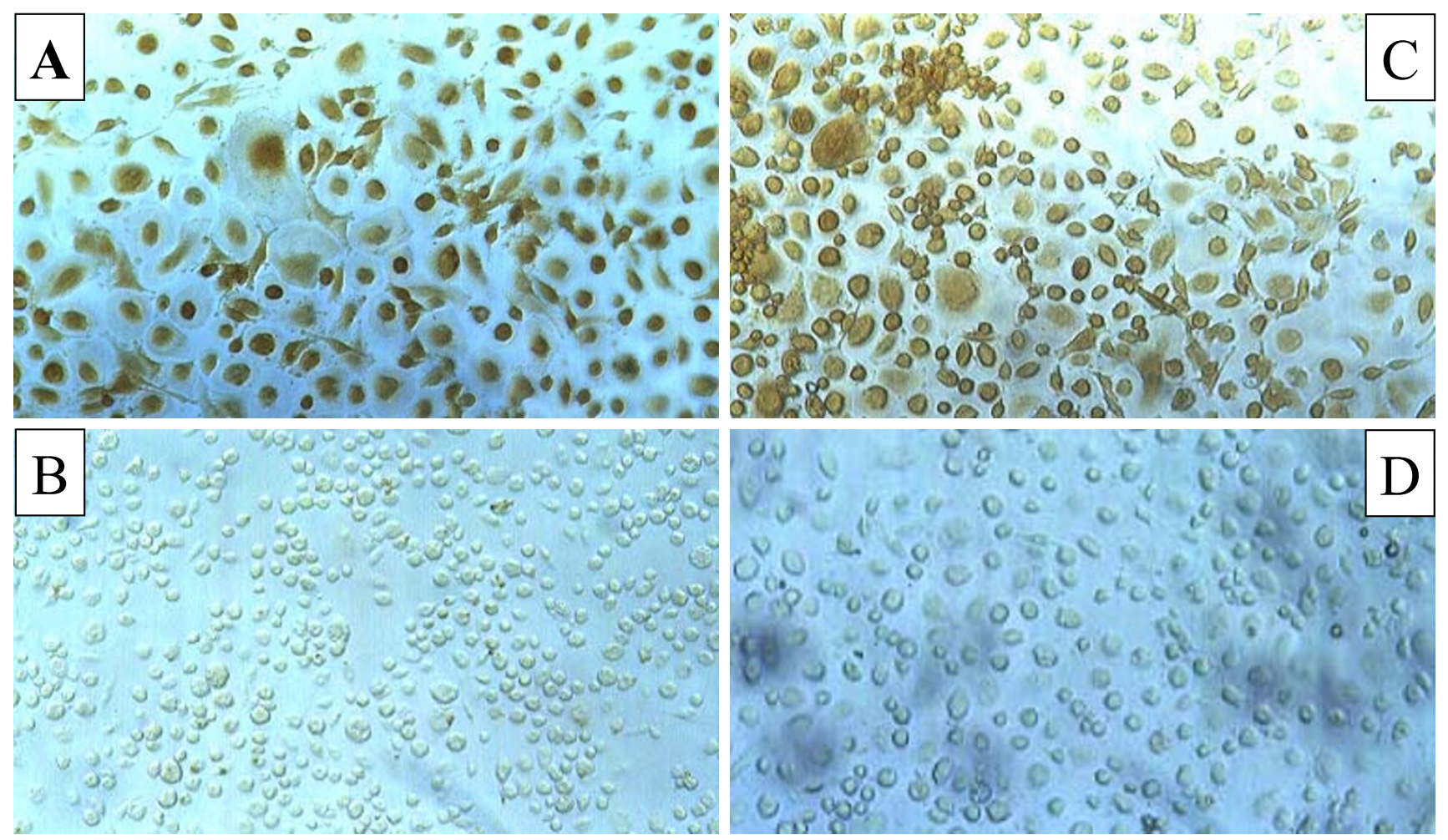

\section{Figure 5}

MnTBAP inhibits nitrotyrosine formation in HIV-infected macrophages. Photomicrographs (optical microscopy) of nitrotyrosine staining in HIV-I-infected macrophages. HIV-I infection enhance the immunocytochemical expression of nitrotyrosine (Panel A) in compared to mock-infected macrophages (Panel B), indicating an increased production of peroxynitrite. Acute treatment with MnTBAP $(30 \mu \mathrm{M})($ Panel D), but not with AZT $(0.05 \mu \mathrm{M})($ Panel C) is able to inhibit in macrophages HIV-related peroxynitrite formation.

might contribute to the profound infectivity reduction induced by MnTBAP treatment that is able to disturb the HIV-1 protein maturation.

\section{Discussion}

The design of this study was based on the crucial importance of infected macrophages in the pathogenesis and progression of HIV-1 infection. During HIV-1 infection the imbalance of the intracellular redox status due to inflammatory stress has been previously reported [28]. Indeed, free radicals are generated following HIV infection of macrophages and microglia $[1,12,17]$. In particular, HIV-1 replication is enhanced under oxidative condition in vitro [29]. For example, in vitro HIV-1 infection of macrophages resulted in superoxide and peroxynitrite production $[30,31]$. Indeed, our findings have shown that immunohistochemical staining for nitrotyrosine, the footprint of peroxynitrite, showed extensive immunoreactivity in HIV-1 macrophages cytoplasm and this overproduction was counteracted by MnTBAP, but not by AZT treatment. In addition, HIV-infected macrophages presented elevated levels of malonildialdehyde, the bio- chemical marker of lipid peroxidation that were inhibited by MnTBAP treatment in a dose-dependent fashion.

Furthermore, significant and sustained inhibition of HIV1 replication was obtained in both acutely and chronically infected macrophages by removing the overt production of peroxynitrite. The effect of MnTBAP, a peroxynitrite decomposition catalyst, upon both the core protein p24 and its precursor $\mathrm{p} 55$ suggests that that free radicals may interfere with HIV-1 protein expression in both acute and chronic infection thus suggesting the important role played by the oxidative status in HIV-1 replication. This is in agreement with previous observations which point out the role of oxidative stress in HIV-1 proteins maturation and folding in both lymphocytes and macrophages [3234]. Moreover, western blot analysis revealed that MnTBAP, by inhibiting both the p24 as the p55 formation, is able to counteract not only the formation, but also the maturation of this core viral protein. To confirm that MnTBAP is able to act on the virus maturation the formation of mature viral particles in intracytoplasmic vacuoles of $\mathrm{M} / \mathrm{M}$ has been analyzed by electron microscopy. It is 

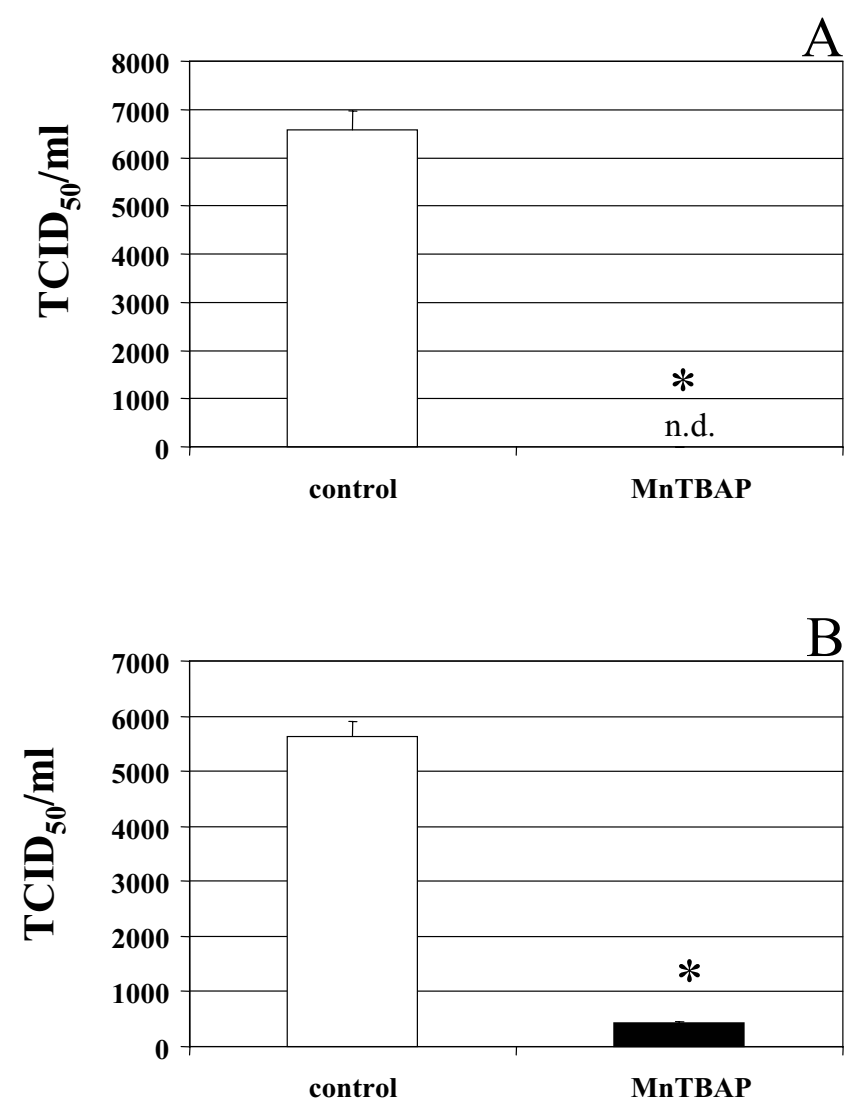

Figure 6

Removal of free radicals by MnTBAP is involved in macrophages HIV replication. Infectivity of virus particles produced by HIV-I-infected macrophages was evaluated on macrophages obtained from a different seronegative donor exposed to serial dilution of supernatants from MnTBAP treated or not-treated HIV-I-infected macrophages. The TCID50/ml was calculated according to Reed and Muench method. MnTBAP reduces TCID50 about a log both in acutelly (Panel A) as in chronically (Panel B) HIV-I-infected macrophages compared to infected and non treated macrophages.

known that the mature HIV-1 particles are accumulated in intracytoplasmic vacuoles in $\mathrm{M} / \mathrm{M}$ before the budding. Indeed, electron microscopic analysis of intracellular compartments in HIV-1 infected M/M has shown that the number of mature virus particles was dramatically decreased by MnTBAP. Moreover, virus particles budding was also fully inhibited in agreement with previous studies where restoration of the oxidative status homeostasis led to the inhibition of HIV-1 budding in macrophage cells. These results so can indicate that MnTBAP disturbs the HIV-1 proteins maturation.

Lack of HIV-1 maturation is correlated to a dramatic reduction of virus infectivity. The production of infectious virus particles by both acutely and chronically infected M/ $M$ was strongly counteracted (a reduction of about 4 and $2 \mathrm{log}$, respectively) by MnTBAP treatment. Nevertheless, complete inhibition of HIV replication was not achieved. This is not surprising since all the HIV inhibitors are less (or even not) active in chronically-infected when compared with acutely-infected macrophages $[27,35,36]$.

It can be hypothetized that the dramatic virus inhibition obtained by the employment of peroxynitrite decomposition catalyst is due to, at least in part, an indirect mechanism on NF-kB pathway. Indeed, it is well known that reactive oxygen species activate $\mathrm{NF}-\mathrm{kB}$ that, in turn, is an obligatory step for HIV-1, together with several viruses, replication $[[37,38]$, although further experiments are needed to confirm this hypothesis].

\section{Conclusion}

However, other than this hypothesis, overall data presented in this article suggest that the inhibition of virus maturation and release can be related to a block of posttranscriptional/post-translational events of the virus life cycle. In fact, MnTBAP treatment substantially modify the expression of virus proteins in chronically (better in acutely) infected macrophages. This structural proteins are crucial for the infectivity of HIV-1. Nevertheless, we cannot exclude that other factors related to peroxynitrite inactivation influence the virus replication. In conclusion our results highlight the role of peroxynitrite generation in HIV replication in human macrophages and show that the removal of peroxynitrite by selective antioxidants such as peroxynitrite decomposition catalysts contribuits to the inhibition of HIV replication in macrophages, the cells acting as a reservoir of the virus. Furthermore, data here reported suggest the potential usefulness of these compounds alone or in association with other antiretrovirals and may represent the basis for alternative and efficient strategies for the treatment of HIV-1 infection.

\section{Methods \\ Compounds}

The peroxynitrite decomposition catalyst MnTBAP was purchased from Alexisis Biochemicals (Switzerland). 3'azido-2', 3'-dideoxythymidine (AZT), an inhibitor of HIV replication, was used as control at concentrations known to be active against HIV-1 replication. All compounds and reagents (with the exception of MnTBAP) were obtained from Sigma (St. Louis, USA). The nucleoside analogue reverse transcriptase inhibitor AZT was diluted in PBS and stored at $-80^{\circ} \mathrm{C}$ before using.

\section{Cell cultures \\ Macrophages and lymphocytes}

Primary $\mathrm{M} / \mathrm{M}$ were prepared and purified as previously described [39]. Briefly, PBMC obtained from healthy HIV- 

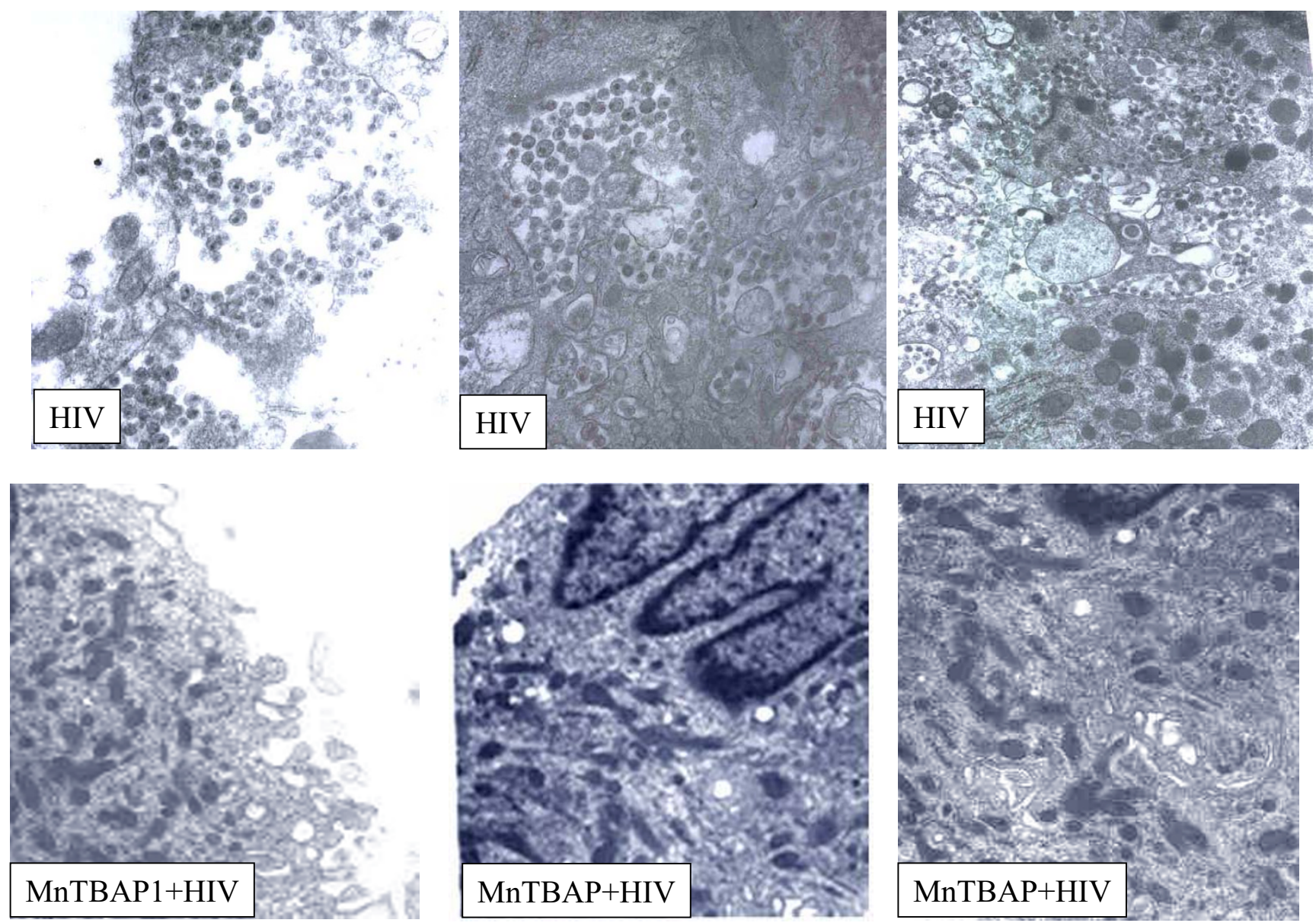

\section{Figure 7}

Electron microscopy of untreated or MnTBAP-treated HIV-I infected macrophages. Untreated macrophages show accumulation of many mature particles, at different stages of maturation, in cytoplasmatic vacuoles and in the extracellular space. By contrast in MnTBAP $(30 \mu \mathrm{M})$ treated macrophages no viral particles are found. This observation support the hypothesis that MnTBAP treatment is able to prevent enveloped and unenveloped virions production.

1-negative donors were separated over Ficoll gradient and seeded in 48-well plates or in glass chamber (for immunocytochemical analysis) at $1.8 \times 10^{6}$ cells/well in $1 \mathrm{ml}$ of RPMI 1640 containing 20\% heat-inactivated, endotoxin and mycoplasma-free fetal bovine serum (Hyclone Laboratories, Inc., Logan, UT), $4 \mathrm{mM}$ L-glutamine (Life Technologies), $50 \mathrm{U} / \mathrm{ml}$ penicillin and $50 \mu \mathrm{g} / \mathrm{ml}$ streptomycin (Life Technologies) (herein after referred to as complete medium). Five days after plating and culturing the PBMC at $37^{\circ} \mathrm{C}$ in a humidified atmosphere enriched with $5 \%$ $\mathrm{CO}_{2}$, non-adherent cells were carefully removed by repeated washings with warmed RPMI 1640, leaving a monolayer of adherent cells which were finally incubated in complete medium. Cells treated under these conditions have been shown to be $>97 \% \mathrm{M} / \mathrm{M}$, as determined by cytofluorimetric analysis $[39,40]$.
Peripheral blood lymphocytes (PBL) were purified from PBMC by repeated adherences to remove monocytes, and then cultured with the same medium as $\mathrm{M} / \mathrm{M}$, supplemented with $2 \mu \mathrm{g} / \mathrm{ml}$ phytohemagglutinin (PHA). Stimulation was carried out for 72 hours; afterward, the medium was discarded, cells were washed three times with RPMI 1640 and the concentration was adjusted to 5 $\times 10^{5}$ cells per $\mathrm{ml}$ of medium supplemented with $50 \mathrm{U} / \mathrm{ml}$ recombinant interleukin-2 (IL-2).

\section{HIV-I isolates}

Two different viral isolates of HIV-1 were used in this study. A monocytotropic isolate of HIV-1 such as HIV- $1_{\mathrm{BaL}}$ was used in all experiments involving primary $\mathrm{M} / \mathrm{M}$. Characteristics and genomic sequence of this strain have been previously described [41-44]. The virus was expanded in $M / M$, whose supernatants were collected, filtered and 
stored at $-80^{\circ} \mathrm{C}$ before use [44]. Characteristics of viral stocks used for this study were $2.1 \times 10^{8}$ HIV-RNA genomes/ml (corresponding to $35 \mathrm{ng}$ of p24 antigen) and $5 \times 10^{3}$ tissue culture infectious doses $50 \%$ per $\mathrm{ml}$ $\left(\mathrm{TCID}_{50} / \mathrm{ml}\right)$ as assessed by virus titration in other primary $\mathrm{M} / \mathrm{M}$ cultures. The prototypic lymphocytotropic strain of HIV-1, named HIV-1 $1_{\text {IIIB }}$ and used to infect PBL, was obtained from acutely infected $\mathrm{H} 9 \mathrm{CD} 4{ }^{+} \mathrm{T}$-lymphocytes cell line, and then expanded in PBMC. Cell free virus present in the supernatants was collected, ultracentrifuged, filtered $(0,22 \mu \mathrm{M})$ and stored at $-80^{\circ} \mathrm{C}$. Titre of HIV-1 $1_{\text {IIв }}$ viral stocks used in this study was $5 \times 10^{6}$ $\mathrm{TCID}_{50} / \mathrm{ml}$, as assessed in $\mathrm{CD} 4^{+} \mathrm{T}$-lymphocytic cell line C8166.

\section{Drug toxicity}

$\mathrm{M} / \mathrm{M}$ and PBL were treated for 14 to 21 days in the presence of different concentrations of MnTBAP. Cell viability of $\mathrm{M} / \mathrm{M}$ and $\mathrm{PBL}$ was visually assessed (and compared to untreated controls) using the trypan blue exclusion method. Briefly, cells were exposed to dye, and then visually examined to determine whether cells take up or exclude dye. The live cells that possess intact cell membranes exclude trypan blue, whereas dead cells do not. Drug toxicity was assessed in the absence of viral infection.

\section{Assessment of drug activity in acutely infected $M / M$}

One day after separation (i.e. 6 days after plating), $M / M$ were treated with various concentrations of drugs (MnTBAP, 0.24, 1.2, 6 and $30 \mu \mathrm{M}$; AZT, $0.05 \mu \mathrm{M})$, and then exposed to $300 \mathrm{TCID}_{50} / \mathrm{ml}$ of $\mathrm{HIV}-1_{\mathrm{Ba}-\mathrm{L}}$ (a virus dose affording a maximal virus production from $M / M$ ). Two hours after virus challenge, $\mathrm{M} / \mathrm{M}$ were washed to remove the viral inoculum, and complete medium containing the appropriate drugs was replaced. Macrophages were then cultured for the duration of the experiments by refunding them with fresh complete medium and drugs every 2 days. Supernatants were collected at different time points for assessment of virus production by analysis of HIV-1 p24 gag Ag production with a commercially available kit (Abbott labs, Pomezia, Italy) as described before. The p24 gag Ag evaluation was repeated at later time points in selected experiments; the geometric mean of p24 gag Ag production of replicates in each experiment was used to determine the effective drug concentration where 50\% and $90 \%$ of viral replication is inhibited $\left(\mathrm{EC}_{50}\right.$ and $\mathrm{EC}_{90}$, respectively), by linear regression of the log of the percent HIV-1-p24 production (compared to untreated controls) versus the log of the drug concentration.

\section{Assessment of antiviral drug activity in chronically infected $M / M$} $\mathrm{M} / \mathrm{M}$ were defined chronically infected when no new rounds of infection occurr in in vitro cultures and the p24 production remains stable. Our previous experience dem- onstrated that such status of chronical infection occurs starting from day 10 after virus challenge. For this purpose, $\mathrm{M} / \mathrm{M}$ were challenged with $300 \mathrm{TCID}_{50} / \mathrm{ml}$ of $\mathrm{HIV}$ $1_{\mathrm{BaL}}$ (in the absence of any drug) at day 0, and p24 gag Ag analysis was carried out from day 6 up to the point when at least two consecutive determinations showed stable production (around day 10-14 in all experiments performed for this purpose). At the time of chronical infection (hereinafter called day 0 for these experiments with chronically-infected $\mathrm{M} / \mathrm{M}$ ), M/M were carefully washed at least twice to remove any virus present in the supernatants, replenished with fresh complete medium containing various concentrations of $\operatorname{MnTBAP}(0.24-30 \mu \mathrm{M})$, Amprenavir $(4 \mu \mathrm{M})$ or AZT $(10 \mu \mathrm{M})$, and cultured under the same conditions as described before. Each drug concentration was run in triplicate or quadruplicate while positive controls were run in sextuplicate. Therefore, unless differently stated, drugs were then added at the time of chronical infection (i.e. day 10), and replaced each time of medium change (i. e. every 2 days).

\section{Assessment of drug activity in acutely-infected PBL}

PBL were plated in 48-well plates in the presence or absence of various concentrations of drugs, and chal-

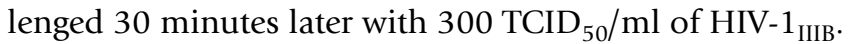
After 2 hours cells were washed, counted, and plated with complete medium containing the appropriate drugs concentrations. Assessment of virus replication was performed by HIV-1-p24 ELISA.

\section{Virus infectivity}

Infectivity of virus particles produced by HIV-1-infected $\mathrm{M} / \mathrm{M}$ was evaluated on $\mathrm{M} / \mathrm{M}$ obtained from a different seronegative donor exposed to serial dilution of supernatants from drug treated or not-treated HIV-1-infected M/ $\mathrm{M}$. The $\mathrm{TCID}_{50} / \mathrm{ml}$ was calculated according to Reed and Muench method.

\section{Western blot analysis}

After cells were washed with phosphate-buffered saline (PBS, BioWhittaker, Walkersville, MD), they were lysed with $0.75 \%$ Triton X-100 lysis buffer containing $300 \mathrm{mM}$ $\mathrm{NaCl}, 50 \mathrm{mM}$ Tris-HCl, pH 7.4, $2 \mu \mathrm{L} / \mathrm{mL}$ DMSO, and a cocktail of protease inhibitors containing $10 \mu \mathrm{g} / \mathrm{mL}$ Leupeptin, $20 \mu \mathrm{g} / \mathrm{mL}$ Aprotinin, $25 \mu \mathrm{M} p$-nitrophenyl guanidinobenzoate ( $\mathrm{pNGb}$ ). After a ten minute incubation in lysis buffer at $4^{\circ} \mathrm{C}$, the cell lysate was clarified by centrifugation for ten minutes at 10,000 rpm. Total protein concentration was determined using the BCA Assay (Pierce, Rockford, IL). Cell lysates were resuspended in SDS sample buffer containing $50 \mathrm{mM}$ dithiotreitol (DTT). Cell lysates $(2 \mu \mathrm{g})$ were then loaded in a $10 \%$ Bis-Tris polyacrylamide gel (Novex, San Diego, CA), after separation by SDS/PAGE, proteins were transferred electrophoretically to nitrocellulose membranes and detected with a mono- 
clonal mouse antibody to HIV-1-p24 (Intracel, Cambridge, MA).

\section{Immunocytochemical Staining}

Immunocytochemical staining for nitrotyrosine was performed on treated or not treated $M / M$. $M / M$ were fixed with $4 \%$ paraformaldeyde dissolved in $0.1 \%$ phosphate buffer ( $\mathrm{pH}$ 7.4). Nonspecific staining was blocked with $3 \%$ normal goat serum in $0.5 \mathrm{M}$ Tris- $\mathrm{HCl}$, $\mathrm{pH} 7.4$ containing $0.2 \%$ Tween 20 for $1 \mathrm{~h}$ at room temperature. All subsequent incubations were carried out in this buffer. For detection of nitrotyrosine immunoreactivity, cells were incubated overnight at $4{ }^{\circ} \mathrm{C}$ with an anti-nitrotyrosine monoclonal Ab (Cayman, 1:500). Treatment with secondary antibody, A/B complex, and DAB were performed by the manufacturer's instructions (Vector ABC Elite Kit, Vector Laboratories).

\section{Malondialdehyde Determinations}

Malondialdehyde (MDA), used as a biochemical marker for lipid peroxidation, was measured by a method previously described [45]. Briefly, cells were homogenized in potassium chloride $(1.15 \%)$ and frozen in liquid nitrogen. Chloroform $(2 \mathrm{ml})$ was then added to each homogenate and then spun for $30 \mathrm{~min}$. The organic layer of the sample was removed and dried under nitrogen gas and reconstituted with $100 \mu \mathrm{l}$ of saline. MDA generation was evaluated by the assay of thiobarbituric acid (TBA)-reacting compounds. The addition of a solution of $20 \mu \mathrm{l}$ of sodium dodecyl sulphate (SDS; $8.1 \%$ ), $150 \mu \mathrm{l}$ of $20 \%$ acetic acid solution (pH3.5), $150 \mu \mathrm{l}$ of $0.8 \%$ TBA and $400 \mu \mathrm{l}$ of distilled water, produced a chromogenic product which was extracted in n-butanol and pyridine. Then, the organic layer was removed and MDA levels read at 532 $\mathrm{nm}$ and expressed as nmol MDA/g prot.

\section{Ultrastructural studies}

Cells for electron microscopy were fixed in $2.5 \%$ glutaraldehyde in PBS pH7.4 at $4{ }^{\circ} \mathrm{C}$ and then washed for 2 hours in PBS and post fixed in osmium tetroxide $1.33 \%$ for 2 hours at $4^{\circ} \mathrm{C}$. After several washes in PBS, the cells were dehydrated in graded alcohol, transferred into toluene, and embedded in Epon 812 resin. The resin was allowed to polymerize in a dry oven at $60^{\circ} \mathrm{C}$ for 24 hours. Thin sections were cut with a glass knife Reichert microtome, stained with toluidine blue and examined on Axioscope microscope. Ultra-thin sections were cut on a Reichert microtome using a diamond knife, stained with uranylacetate-lead-hydroxide and evaluated and photographed on a Philips electron microscope CM 10 (Philips).

\section{Statistics}

The differences in the $\mathrm{EC}_{50}$ in different cell populations and under different conditions of infection were assessed using the Student's t test. Results are given as mean \pm sem.
Statistical analysis was performed using ANOVA followed by Student-Newman-Keuls. $\mathrm{P}<0.05$ was considered statistically significant.

\section{Competing interests}

The author(s) declare that they have no competing interests.

\section{Authors' contributions}

SA conceived of the study, carried out the virus infectivity assays and drafted the manuscript. CM conceived of the study, carried out the immunocytochemistry and biochemical assays and drafted the manuscript. AR participated in the infectious assays and performed the statistical analysis. MP carried out the infectious studies, cell death analysis and helped to draft the manuscript. TG, LM and AM carried out the electron microscopy studies. CFP conceived of the study, and participated in its design and coordination. VM conceived of the study, and participated in its coordination and helped to draft the manuscript. All authors read and approved the final manuscript.

\section{Acknowledgements}

The work was supported by funds from PRIN 2004 and PRIN 2005. We would like to thank Mrs. Teresa Aversa for overall help with the experiments. We thank Mrs Fabiola Di Santo and Mrs Patrizia Saccomandi for technical assistance.

\section{References}

I. Sonza S, Multimer HP, Oelrichs R, Jardine D, Harvey K, Dunne A, Purcell FD, Birch $C$, Crowe MS: Monocytes harbour replicationcompetent, non latent HIV-I in patients on highly active antiretroviral therapy. AIDS 200I, I5:17-22.

2. Aquaro S, Bagnarelli P, Guenci T, De Luca A, Clementi M, Balestra E, Caliò $R$, Perno CF: Long term survival and virus production in human primary macrophages infected by human immunodeficiency virus. J Med Virol 2002, 68:479-488.

3. Crowe SM, Mills J, Kirihara J, Boothman J, Marshall JA, McGrath MS: Full-length recombinant CD4 and recombinant gp I 20 inhibit fusion between HIV infected macrophages and uninfected CD4-expressing T-lymphoblastoid cells. AIDS Res Hum Retroviruses 1990, 6:1031-1037.

4. Badley AD, Dockrell D, Simpson M, Schut R, Lynch DH, Leibson P, Paya CV: Macrophage-dependent apoptosis of CD4+ $\mathrm{T}$ lymphocytes from HIV-infected individuals is mediated by FasL and Tumor Necrosis Factor. J Exp Med 1997, I 85:55-64.

5. Herbein G, Mahlknecht U, Batliwalla F, Gregersen P, Pappas T, Butler J, O'Brien WA, Verdin E: Apoptosis of CD8+ T cells is mediated by macrophages through interaction of HIV gpl20 with chemokine receptor CXCR4. Nature 1998, 395:189-194.

6. Mastino A, Grelli S, Piacentini M, Oliveiro S, Favalli C, Perno CF, Garaci E: Correlation between induction of lymphocyte apoptosis and prostaglandin E2 production by macrophages infected with HIV. Cell Immunol 1993, I 52: I 20- I30.

7. Aquaro S, Panti S, Caroleo MC, Balestra E, Cenci A, Forbici F, Ippolito G, Mastino A, Testi R, Mollace V, Caliò R, Perno CF: Primary macrophages infected by human immunodeficiency virus trigger CD95-mediated apoptosis of uninfected astrocytes. J Leukoc Biol 2000, 68:429-435.

8. Mollace V, Salvemini D, Riley DP, Muscoli C, lannone M, Granato T, Masuelli L, Modesti A, Rotiroti D, Nistico' R, Bertoli A, Perno CF, Aquaro S: The contribution of oxidative stress in apoptosis of human-cultured astroglial cells induced by supernatants of HIV-I-infected macrophages. J Leukoc Biol 2002, 7 I:65-72.

9. Muscoli C, Salvemini D, Paolino D, lannone M, Palma E, Cufari A, Rotiroti D, Perno CF, Aquaro S, Mollace V: Peroxynitrite decomposi- 
tion catalyst prevents apoptotic cell death in a human astrocytoma cell line incubated with supernatants of HIVinfected macrophages. BMC Neurosci 2002, 3: I3.

10. Swingler S, Mann A, Jacque J, Brichacek B, Sasseville VG, Williams K, Lackner AA, Janoff EN, Wang R, Fisher D, Stevenson M: HIV-I Nef mediates lymphocyte chemotaxis and activation by infected macrophages. Nat Med 1999, 5:997-1003.

II. Stevenson M: HIV-I pathogenesis. Nat Med 2003, 9:853-860

12. Garaci E, Aquaro S, Lapenta C, Amendola A, Spada M, Covaceuszach S, Perno CF, Belardelli F: Anti-nerve growth factor Ab abrogates macrophage-mediated HIV-I infection and depletion of CD4+ T lymphocytes in hu-SCID mice. Proc Natl Acad Sci USA 2003, 100:8927-8932

13. Li S, Juarez J, Alali M, Dwyer D, Collman R, Cunningham A, Naif HM: Persistent CCR5 utilization and enhanced macrophage tropism by primary blood human immunodeficiency virus type I isolates from advanced stages of disease and comparison to tissue-derived isolates. J Virol 1999, 73:974|-9755.

14. Dröge W, Eck HP, Mihm S: Oxidant-antioxidant status in human immunodeficiency virus infection. Methods Enzymol 1994, 233:594-60l.

15. Olinski R, Gackowski D, Foksinski M, Rozalski R, Roszkowski K, Jaruga P: Oxidative DNA damage: assessment of the role in carcinogenesis, atherosclerosis, and acquired immunodeficiency syndrome. Free Radic Biol Med 2002, 33: 192-200.

16. Aukrust P, Muller F, Svardal AM, Ueland T, Berge RK, Froland SS: Disturbed glutathione metabolism and decreased antioxidant levels in human immunodeficiency virus-infected patients during highly active antiretroviral therapy - potential immunomodulatory effects of antioxidants. J Infect Dis 2003, I 88:232-238.

17. Mollace V, Nottet HSLM, Clayette P, Turco C, Muscoli C, Salvemini $D$, Perno CF: Oxidative stress and neuroAIDS: triggers, modulators and novel antioxidants. Trends Neurosci 200I, 24:4II-4I6

18. Palamara AT, Perno CF, Aquaro S, Buè MC, Dini L, Garaci E: Glutathione inhibits HIV replication by acting at late stages of the virus life cycle. AIDS Res Hum Retroviruses 1996, I 2: I537-I54 I.

19. Garaci E, Palamara AT, Circolo MR, D'Agostini C, Abdel-Latif MS Aquaro S, Lafavia E, Rotilio G: Intracellular GSH content and HIV replication in human macrophages. J Leukoc Biol 1997, 62:54-59.

20. Nottet HS, Gendelman HE: Unraveling the neuroimmune mechanisms for the HIV-I-associated cognitive/motor complex. Immunol Today 1995, I 6:44 I-448.

2I. Price RW: The cellular basis of central nervous system HIV-I infection and the AIDS dementia complex: introduction. NeuroAIDS 1996, I(I): I-29.

22. Ghafouri M, Amini S, Khalili K, Sawaya BE: HIV-I associated dementia: symptoms and causes. Retrovirology 2006, 3:28.

23. Weisiger RA, Fridovich I: Superoxide dismutase. Organelle specificity. J Biol Chem 1973, 248:3582-3592.

24. Flores SC, Marecki JC, Harper KP, Bose SK, Nelson SK, McCord JM Tat protein of human immunodeficiency virus type I represses expression of manganese superoxide dismutase in HeLa cells. Proc Natl Acad Sci USA 1993, 90:7632-7636.

25. Westendorp MO, Frank R, Ochsenbauer C, Stricker K, Dhein J, Walczak $H$, Debatin KM, Krammer PH: Sensitization of $T$ cells to CD95-mediated apoptosis by HIV-I Tat and gp I20. Nature 1995, 375:497-500.

26. Muscoli C, Cuzzocrea S, Riley DP, Zweier JL, Thiemermann C, Wang $Z Q$, Salvemini D: On the selectivity of superoxide dismutase mimetics and its importance in pharmacological studies. $\mathrm{Br}$ J Pharmacol 2003, 140:445-460.

27. Perno CF, Newcomb FM, Davis DA, Aquaro S, Humphrey RW, Caliò $R$, Yarchoan $R$ : Relative potency of protease inhibitors in monocytes/macrophages acutely and chronically infected with human immunodeficiency virus. J Infect Dis 1998 I 78:413-422.

28. Kalebic T, Kinter A, Poli G, Anderson ME, Meister A, Fauci AS: Suppression of human immunodeficiency virus expression in chronically infected monocytic cells by Glutathione, Glutathione Ester, and N-Acetylcysteine. Proc Natl Acad Sci USA 1991, 88:986-990.
29. Nabel G, Baltimore D: An inducible transcription factor activates expression of human immunodeficiency virus in $\mathbf{T}$ cells. Nature 1987, 326:71 I-713.

30. Boven LA, Gomes L, Hery C, Gray F, Verhoef, Portegies P, Tardieu $M$, Nottet HS: Increased peroxynitrite activity in AIDS dementia complex: implications for the neuropathogenesis of HIV-I infection. J Immunol 1999, I 62:43 I9-4327.

31. Boven LA, Middel J, Verhoef J, De Groot CJ, Nottet HS: Monocyte infiltration is highly associated with loss of the tight junction protein zonula occludens in HIV-I-associated dementia. Neuropathol Appl Neurobiol 2000, 26:356-60.

32. Davis DA, Yusa K, Gillim LA, Newcomb FM, Mitsuya H, Yarchoan Conserved cysteines of the human immunodeficiency virus type I protease are involved in regulation of polyprotein processing and viral maturation of immature virions. J Virol 1999, 73: I 156-64.

33. Arp J, Rieder MJ, Unrquhart B, Freeman D, Tucker MJ, Krizova A, Lehmann D, Dekaban GA: Hypersensitivity of HIV-I-infected cells to reactive sulfonamide metabolites correlated to expression of the HIV-I viral protein tat. J Pharmacol Exp Ther 2005, 314:1218-25.

34. Gulow K, Kaminski M, Darvas K, Suss D, Li-Weber M, Krammer PH: HIV-I trans-activator of transcription substitutes for oxidative signaling in activation-induced $\mathbf{T}$ cell death. J Immunol 2005, I 74:5249-60

35. Perno CF, Aquaro S, Rosenwirth B, Balestra E, Peichl P, Billich A, Villani $N$, Caliò R: In vitro activity of inhibitors of late stages of the replication of HIV in chronically infected macrophages. J Leukoc Biol 1994, 56:38I-386.

36. Aquaro S, Caliò R, Balzarini J, Bellocci MC, Garaci E, Perno CF: Macrophages and HIV infection: therapeutical approaches toward this strategic virus reservoir. Antiviral Res 2002, 55:209-225.

37. Lenardo MJ, Fan CM, Maniatis T, Baltimore D: The involvement of NF-kappa $B$ in beta-interferon gene regulation reveals its role as widely inducible mediator of signal transduction. Cell 1989, 57:287-294.

38. Brach MA, De Vos S, Arnold C, Gruss HJ, Mertelsmann R, Herrmann F: Leukotriene B4 transcriptionally activates interleukin-6 expression involving NK-chi B and NF-IL6. Eur J Immunol I992, 22:2705-27II.

39. Aquaro S, Perno CF: Assessing the relative efficacy of antiretroviral activity of different drugs on macrophages. In Methods Mol Biol Volume 304. Edited by: Zhu T. Human Press, Totowa, NJ; 2005:445-453.

40. Aquaro S, Menten P, Struyf S, Proost P, Van Damme J, De Clercq E, Schols D: The LD78beta isoform of MIP-Ialpha is the most potent CC-chemokine in inhibiting CCR5-dependent human immunodeficiency virus type I replication in human macrophages. J Virol 2001, 75:4402-4406.

4I. Popovic M, Sarnagadharan MG, Read E, Gallo RC: Detection, isolation, and continuous production of cytopathic retroviruses (HTLV-III) from patients with AIDS and pre-AIDS. Science 1984, 224:497-500.

42. Gartner S, Markovits P, Markovits DM, Kaplan MH, Gallo RC, Popovic $M$ : The role of mononuclear phagocytes in HTLV-III/LAV infection. Science 1986, 233:215-219.

43. Cenci A, Perno CF, Menzo S, Clementi M, Erba F, Tavazzi B, Di Pierro $D$, Aquaro $S$, Caliò R: Selected nucleotide sequence of the pol gene of the monocytotropic strain HIV type I BaL. AIDS Res Hum Retroviruses 1997, 13:629-632.

44. Perno CF, Bergamini A, Pesce CD, Milanese G, Capozzi M, Aquaro S, Thaisrivongs S, Tarpley WG, Zon G, D'agostini C, Rocchi G, Garaci $E$, Caliò R: Inhibition of the protease of human immunodeficiency virus blocks replication and infectivity of the virus in chronically infected macrophages. J Infect Dis 1993, 168: | |48-1156.

45. Ohkawa $\mathrm{H}$, Ohishi $\mathrm{H}$, Yagi K: Assay for lipid peroxides in animal tissue by thiobarbituric acid reaction. Anal Biochem 1979 , 95:351-358 